\title{
Formulating a Modern Instructional Model to Help Improve the Persuasive Writing of Students
}

\author{
Farous Izwan Abdul Aziz, Seriaznita Mat Said
}

\begin{abstract}
Persuasive writing is an important writing genre for students to master as they are required to compose strong arguments for research papers and essays for tertiary level education. However, English persuasive writing is introduced late to secondary school students and there appears to be a lack of specific instructions for ESL students in secondary schools. This lack of attention and specific instruction can cause students to produce weak persuasive essays as a result. The purpose of this case study is to uncover the reasons behind the students' difficulties with argumentative writing to formulate a model that can be a relevant teaching tool for classroom instruction. This is done by analyzing the essays of 150 low-scoring secondary school students with Toulmin's Model as well as a set of questionnaires that are targeted at the students and the interviews that were conducted with their teachers. From the results, the researcher can formulate a prototype modern persuasive writing model that can be used in the English classroom as a teaching tool.
\end{abstract}

Keywords: Toulmin's Model, Persuasive Writing, Secondary School Students

\section{INTRODUCTION}

\section{Background}

Persuasive writing is an essential skill [1] that Malaysian secondary school students need to master for as they are expected to produce multiple academic research papers during their university career [2][3]. Persuasive writing also opens up numerous opportunities for a career after graduation [4][5] allowing them to become politicians, lawyers, business people and advertisers. However, persuasive writing is very challenging for students despite their natural ability to argue as adolescents even though it improves as they mature [6][7]. In fact, secondary school students can compose effective persuasive essays but lack the ability to strengthen their arguments [7]. A possible reason why students produce mediocre persuasive essays is because the teachers are not able to adequately teach them the genre [8][9]. However, another reason the students are not expert persuasive writers is because they are only introduced to English persuasive writing during their upper secondary school years; Form 4 and Form 5 [10]. Limited exposure to a complex genre such as persuasive writing would cause students to be pressured as they attempt to compose their essays during examinations [11]. The way persuasive writing is being taught in schools also does not help as the process of writing instruction in

Revised Manuscript Received on October15, 2019

* Correspondence Author

Farous Izwan Abdul Aziz*, Faculty of Social Science and

Humanities, Universiti Teknologi Malaysia KL, Jalan Sultan Yahya Petra, Kampung Datuk Keramat, 54100 Kuala Lumpur, Wilayah Persekutuan Kuala Lumpur, Malaysia. Email: farous.izwan@gmail.com

Seriaznita Mat Said, Faculty of Social Science and

Humanities, Universiti Teknologi Malaysia KL, Jalan Sultan Yahya Petra, Kampung Datuk Keramat, 54100 Kuala Lumpur, Wilayah Persekutuan Kuala Lumpur, Malaysia. Email: Seriaznita.k1@utm.my
Malaysia is considered too exam-oriented and instructor-centred [12][7]. Numerous strategies being used in the classroom include copying a model essay [12][7], the Five-Paragraph Essay Style [13] and the mind-mapping strategy [14].

There have been numerous persuasive writing models developed in the past, which include the Ooi \& Seelan's Model [15], the Argument-Driven Inquiry (ADI) Model [16], the Flower \& Hayes' Model [17], the Socio-Cognitive Model [18] the Hamburger Model and the Dagwood Model [19]. Nonetheless, while these models can provide a satisfactory foundation for persuasive writing instruction, the Toulmin's Model [20] is the most definitive [21 \} model as it is practical, accurate, audience-focused, flexible and allows for new ideas to be generated [22][23][6]. Fig. 1 displays a diagram of the Toulmin's Model.

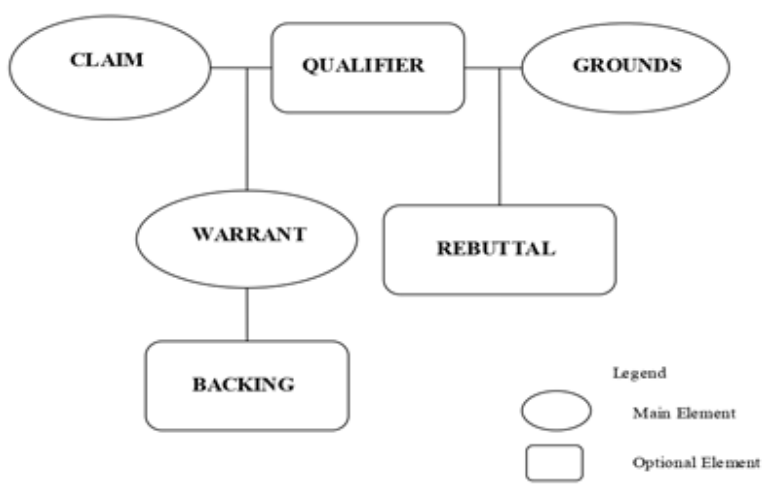

Fig. 1 Toulmin's Model of Argumentation (Toulmin, 2003)

As shown in Fig. 1, the elements presented in this model are separated into two categories: the main elements and optional elements. Table I briefly describes each of the elements.

Table I: Description of Persuasive Elements

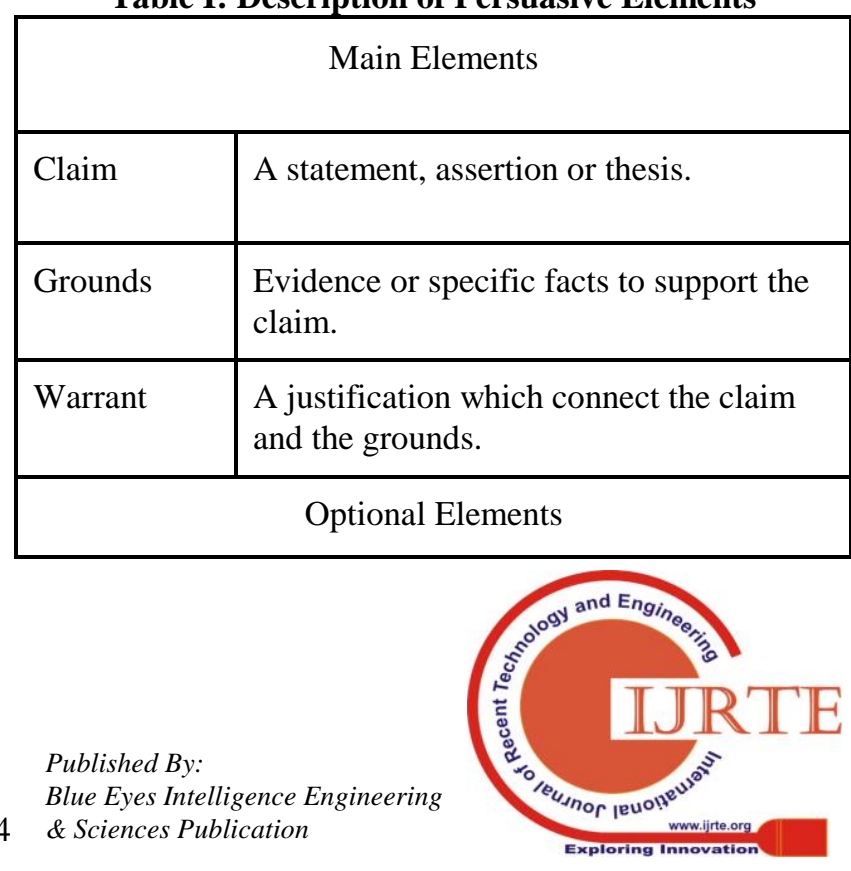




\begin{tabular}{|l|l|} 
Qualifier & $\begin{array}{l}\text { Used to show how important the arguer } \\
\text { feels about their argument and how much } \\
\text { they want the audience to take it seriously. }\end{array}$ \\
\hline Rebuttal & $\begin{array}{l}\text { Statements added to the argument to show } \\
\text { that the writer is aware of the opposing } \\
\text { viewpoint and takes it into consideration. }\end{array}$ \\
\hline Backing & $\begin{array}{l}\text { Provides additional justification for the } \\
\text { warrants, consisting of strong evidence in } \\
\text { order to support its reasoning. }\end{array}$ \\
\hline
\end{tabular}

According to studies by Varghese and Abraham [24], Qin and Karabacak [25], Lunsford [26], Suhartoyo, Mukminatan and Laksmi [27], and Zainuddin and Rafik-Galea [6], the application of Toulmin's Model greatly improves the students' writing skills and their abilities to create logical arguments. Since then, there have been even more recent studies involving Toulmin and persuasive writing in Malaysia.

Lee [28] investigated how Malaysian undergraduate writers expressed their stance (claim) and stance-support (grounds) in their arguments. Through the utilization of Toulmin's Model, the results of the study show that the senior undergraduates were able to provide better and clearer stance-support compared to the first-year undergraduates. This was also indicated by the total mean scores based on IELTS writing band description.

Additionally, Vasu, Nimehchisalem, Fung and Rashid [29] studied the implementation and effects of a self-assessment checklist upon an undergraduate writing classroom over a period of five weeks. The students claimed that the checklist effectively motivated them to write, allowed them to be aware of their writing prowess, helped them understand argumentative writing better, allowed them to be more independent writers and assisted them in writing more systematically.

Finally, Nimehchisalem [30] presented a Pyramid of Argumentation (PoA) as an integrated model for assessing persuasive writing. The PoA integrates recent and ancient theories of argumentation, linguistic competence and language assessment. As a framework, the PoA peer-review and self-assessment checklists can be developed to scaffold the students' learning of argumentative writing. Nimehchisalem [30] also claims that the framework may help teachers to improve the validity of their assessment by providing a comprehensive account of argumentative writing constructs.

\section{MATERIALS AND METHODOLOGY}

For this study, one of the main instruments used to collect data was a set of essay writing prompts consisting of four questions based on the SPM format for the students to write their essays about. The prompts were in the form of argumentative essays questions selected from past SPM examination papers $(2007,2008,2009 \& 2010)$ :

Q1: The more A's we score on our examination, the better students we become. What is your opinion?

Q2: "Teenagers today are only interested in entertainment" Do you agree? Support your opinion.
Q3: School children should not have long holidays. Do you agree? Support your opinion.

Q4: The internet is mostly a good thing. Do you agree? Support your opinion.

Other materials include a questionnaire which was filled out by the students and interview questions for one English teacher from each of the schools. For the purpose of this study, three local secondary schools in the Klang area were selected, TM, WM and LK, as the top students from each school are most likely to enrol in universities after passing their STPM (Sijil Tinggi Pelajaran Malaysia) and matriculation. The students used in this study will comprise of 150 Form Four students. The students were selected to determine the effectiveness of their argumentative writing skills. Table II shows the average scores and grade averages from the SPM examination in English for the three schools from 2016.

Table II: Schools, Average Scores and Grade Average in English (SPM, 2016)

\begin{tabular}{|c|c|c|}
\hline Name of School & $\begin{array}{c}\text { Average Scores in } \\
\text { English (\%) }\end{array}$ & $\begin{array}{c}\text { Average Grade in } \\
\text { English }\end{array}$ \\
\hline WM & 91.46 & 5.29 \\
\hline LK & 89.8 & 4.93 \\
\hline TM & 65 & 3.73 \\
\hline
\end{tabular}

Data was collected in the form of essay samples which will be written by the students based on writing prompts provided by the researcher. The samples will consist of 150 essays from upper secondary students (N1: 150). The essays were graded and analysed for persuasive features according to Toulmon's Model (claim, grounds, warrant, qualifier, rebuttal and backing). The rubric, which was provided by Tunku Abdul Rahman University College (TARUC) will also be utilized to grade the students. The reason this rubric was utilized instead of the standard SPM marking scheme is because it is specifically tailored to assess persuasive writing essays as the SPM marking scheme is far too generic to be used on its own. Additional data were also gathered through questionnaires collected from the students and interviews with the teachers.

\section{FINDINGS AND DISCUSSIONS}

Prior to any complex analysis, all 150 essays were marked and scored by the researcher before being checked again by the rater, who is an experienced lecturer. Most of the marks coincide, but since the rater was more experienced, the rater's scores were chosen instead. In addition to the rubric, an SPM mark range was also used as shown in Table IV.

Table IV: Mark Range, Grade and Criteria for SPM English Continuous Writing

\begin{tabular}{|l|l|l|}
\hline Mark Range & Grade & Criteria \\
\hline $44-50$ & A & Excellent \\
\hline $38-43$ & B & Good \\
\hline $32-37$ & C & Satisfactory \\
\hline
\end{tabular}




\begin{tabular}{|l|l|l|}
\hline $26-31$ & D & Fair \\
\hline $20-25$ & E & \multirow{2}{*}{ Unsatisfactory } \\
\hline $14-19$ & U(i) & \\
\hline $8-13$ & U(ii) & \\
\hline $0-7$ & U(iii) & \\
\hline
\end{tabular}

such criteria could prevent students from properly composing their persuasive arguments. Finally, students strongly agree that 'Watching a lot of English TV', 'Listening to English Songs' and 'Interacting with People Online' are activities that factor into their persuasive writing level.

The teachers reveal during the interview that the students

Table IV shows that the passing grades are A, B, C and D. Grades E, U(i), U(ii), and U(iii) are considered poor and unsatisfactory, therefore they are failing grades. Table $\mathrm{V}$ displays the scores of the collected essays from the students of TM, WM and LK.

Table V: Students' Essay Scores

\begin{tabular}{|l|l|l|l|}
\hline Grade & $\begin{array}{l}\text { Number of } \\
\text { Students }\end{array}$ & $\begin{array}{l}\text { Percentage } \\
(\%)\end{array}$ & $\begin{array}{l}\text { Scores for } \\
\text { each Grade }\end{array}$ \\
\hline A & 0 & 0 & 0 \\
\hline B & 10 & 6.67 & 400 \\
\hline C & 43 & 28.67 & 1469 \\
\hline D & 52 & 34.67 & 1508 \\
\hline E & 18 & 12 & 413 \\
\hline U(i) & 12 & 8 & 196 \\
\hline U(ii) & 10 & 6.67 & 107 \\
\hline U(iii) & 5 & 3.3 & 7 \\
\hline Total & 150 & 100 & 4100 \\
\hline Average Score & & $27.33(\mathrm{D})$ \\
\hline
\end{tabular}

As seen in Table $\mathrm{V}$, the highest grade that was achieved is a B and only 10 students $(6.67 \%)$ from a total of 150 students managed to earn it. As for the low-scoring students, 97 $(64.67 \%)$ students received a grade of D and lower. This results in the total average score being 27.33 which is a ' $D$ ' according to the SPM marking rubric. The students who received a low score produced essays which were incomplete or were unable to fulfil the task. An excerpt from one of the low-scoring essays can be seen in Example 1

"First of all, the internet can make people or students distracted (Claim). They will not done their work and it will effect their day (Grounds). This is because they thought they could do their work through (the) internet, but they will open another website for other intention(s) (Grounds)."

\section{Example 1: Sample Essay Excerpt}

According to Toulmin [20], the foundation for a good argument requires a 'Claim', 'Ground' and 'Warrant' and this example fails to meet those criteria. There is also no utilization of the optional elements. In addition, there are grammatical errors which have been underlined and missing articles in the paragraph which are shown in the parentheses. Many of the low-scoring essays have display incomplete arguments, a limited vocabulary, weak grammatical comprehension, short paragraphs and spelling errors. Their introductions lack a proper stance and thesis statement while their body paragraphs often stray from the topic sentence.

According to the students' responses from their questionnaires, it was determined that 'Teachers', 'Reading' and 'General Knowledge' strongly affect their persuasive writing capabilities. As for the criteria that they determine to be important during the persuasive writing process, 'Grammar', 'Vocabulary', 'Task Fulfilment' and 'Spelling' are considered the most important by students. The focus on

\section{CONCLUSION}

This research attempts to uncover the challenges students experience while composing a persuasive essay. According to the findings gathered from the essay samples, the students are mostly capable in structuring the basic argumentative elements in persuasive writing. However, most of them are only able to use the elements that form the foundation of an argument (claim, grounds and warrant) and do not fully utilize the optional elements (qualifier, rebuttal and backing). The results also reveal that students are hampered by a limited vocabulary, limited grammatical knowledge, their ability to fulfil the task and spelling. The interview with the teachers also reveals similar results. In addition, the teachers observed that the students are unmotivated in writing and reading. They also claim that the students lack both general knowledge and knowledge of current events. Based on the results of the study, the researcher formulated a model tentatively known as the 'Aziz Model' as shown in Fig. II.

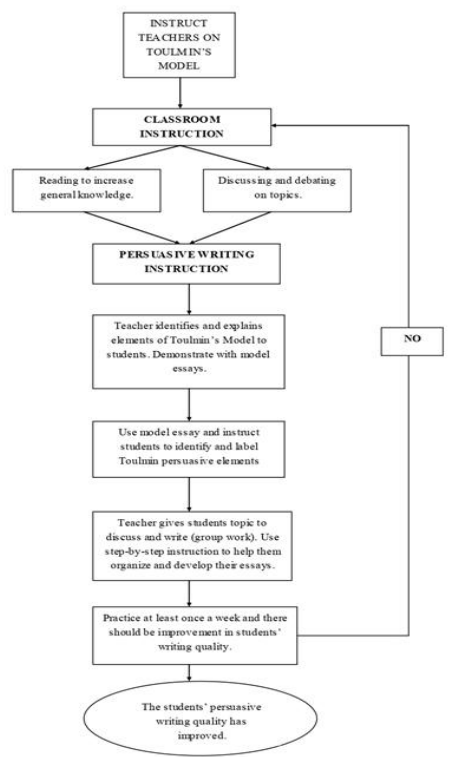

Figure II: Aziz Model

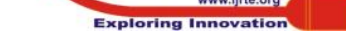


For the Aziz Model to become a reality, it needs to be tested and perfected. Therefore, a case study implementing the model needs to be conducted so that the results can be assessed. Before any testing can be done, a pre-test needs to be performed so that a comparison can be done after the teachers and students have ample practice of using the model. This should be implemented once a week during a two-period English class and should begin in their first year of secondary school. The researcher believes that by implementing this model, it is possible for students to improve their persuasive writing skills.

\section{REFERENCES}

1. Allagui, B. Investigating the Quality of Argument Structure in First-Year University Writing. In English Language Teaching Research in the Middle East and North Africa (pp. 173-196). PalgraveMacmillan, Cham; 2019. 173-196.

2. Conley, D. T. The challenge of college readiness. Educational Leadership, 64(7); 2007. 23-29.

3. Goldman, J. Six High-Leverage Writing Practices for Teaching English Language Learners in English Language Arts. In Teaching the Content Areas to English Language Learners in Secondary Schools, Spriner, Cham; 2019. 65-84.

4. Darus, S. \& Khor, H. C. Common Errors in Written English Essays of Form One Chinese Students: A Case Study. European Journal of Social Sciences, 10(2); 2009. 242-253.

5. Majumdar, S. B. Money Matters: Indigenous and Foreign Coins in the Malabar Coast (Second Century BCE-Second Century CE. Imperial Rome, Indian Ocean Regions and Muziris: New Perspectives on Maritime Trade; 2016. 395-423

6. Zainuddin, S. Z., \& Rafik-Galea, S. (2016). Effects of Training in the Use of Toulmin's Model on ESL Students' Argumentative Writing and Critical Thinking Ability. Malaysian Journal of Languages and Linguistics (MJLL), 5(2); 2016. 114-133.

7. Aziz, F. I. B. A., \& Said, S. B. M. Developing a persuasive writing model for secondary school. Educational Research for Policy and Practice; 2019. 1-16.

8. Graham, S., \& Perin, D. A meta-analysis of writing instruction for adolescent students. Journal of Educational Psychology, 99(3); 2007. 445-476.

9. Lam, Y. W., Hew, K. F. T., \& Chiu, K. F. Improving argumentative writing: Effects of a blended learning approach and gamification. Language Learning \& Technology; 2018.

10. Rashid, S., \& Chan, S. H. Exploring the Interplay of Mode of Discourse and Proficiency Level in Esl Writing Performance: Implications for Testing. The English Teacher, XXXVII; 2017. 105-122.

11. El-daly, H.M. Linguistic Aspects of the Narrative and Persuasive Written Productions of Arabic and Spanish Speakers: Focus on the Role of Explicit Knowledge of Grammar. Arab World English Journal. Vol. 2 (1); 2011. 77-122. United Arab Emirates University.

12. Tan, K. E. Writing English Essays Within Dominant Discourses In Malaysian Schools. Malaysian Journal of Educators and Education, 21; 2006. 23-45.

13. Smith, S. The Art of Rhetoric: Understanding the How of Persuasive Writing; 2008. Date of Recovery Febuary 72019 from http://www.kathrynpieplow.pwrfaculty.org/wp-content/uploads/20 10/08/Smith-Questions.pdf

14. Yunus, M., \& Chien, C. H. The Use of Mind Mapping Strategy in Malaysian University English Test (MUET) Writing, (April); 2016. pp. 619-626.

15. Ooi, J \& Seelan, S. SPM Composition: Learning Through Diagrams. UG Press Sdn. Bhd, Selangor Darul Ehsan; 2011.

16. Sampson, V., Enderle, P., Grooms, J., \& Witte, S. Writing to learn by learning to write during the school science laboratory: Helping middle and high school students develop argumentative writing skills as they learn core ideas. Science Education, 97(5); 2013. 643-670.

17. Flower, L., \& Hayes, J. R. J. R. A cognitive process theory of writing. College Composition and Communication, 32(4); 1981. $365-387$.
18. Fei-Wen, C. A socio-cognitive modeling approach to teaching english argumentation. Asian ESP Journal, 6(1); 2010. 120-146.

19. Stambaugh, T. William and Mary for Beginners: Research Based Models. College of William and Mary: Centre for Gifted Education; 2011.

20. Toulmin, S. The Uses of Argument. Cambridge University Press; 2003.

21. Hitchcock, D. Good Reasoning on the Toulmin Model. In On Reasoning and Argument; 2017. 371-387.

22. Karbach, J. Using Toulmin's model of argumentation. Journal of Teaching Writing, 6(1); 1987. 81-91.

23. Nimehchisalem, V., \& Mukundan, J. Determining the evaluative criteria of an argumentative writing scale. English Language Teaching, 4(1); 2011. pp. 58-70.

24. Varghese, S.A. \& Abraham, S.A. Undergraduates arguing a case. Journal of Second Language Writing, 7; 1998. 286-306.

25. Qin, J., \& Karabacak, E. The analysis of Toulmin elements in Chinese EFL university argumentative writing. System, 38(3); 2010. 444-456.

26. Lunsford, K. J. (2002). Contexualizing Toulmin's Model in the Writing Classroom: A Case Study. Written, 19; 2002. 109-174.

27. Suhartoyo, E., Mukminatan, N., \& Laksmi, E. D. The Effect of Toulmin's Model of Argumentation Within TWPS Strategy on Students' Critical Thinking on Argumentative Essay. Jurnal Pendidikan Humaniora, 3 (2); 2015. 143-153.

28. Lee, G. I. Stance \& Stance-Support Strategies in English Argumentative Writing by Malaysian Undergraduate Writers, Universiti Putra Malaysia; 2017.

29. Vasu, K., Nimehchisalem, V., Fung, Y. M., \& Rashid, S. M. The Usefulness and Effectiveness of Argumentative Writing Self-assessment Checklist in Undergraduate Writing Classrooms. International Journal of Academic Research in Business and Social Sciences, 8(4); 2018. 202-219.

30. Nimehchisalem, V. Pyramid of Argumentation: Towards an Integrated Model for Teaching and Assessing ESL Writing. Language \& Communication, 5(2); 2018. 185-200.

\section{AUTHORS PROFILE}

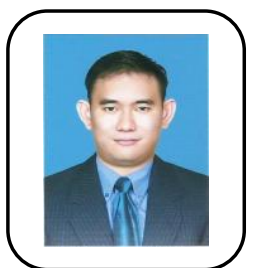

Farous Izwan Bin Abdul Aziz is a Ph.D TESL student in Universiti Teknologi Malaysia. He obtained a Bachelor's degree in TESL from Universiti Teknologi Mara and a Master's Degree in Education (TESL) from Universiti Teknologi Malaysia. He has so far published two articles: "Persuasive Writing: How Students Argue" in Sains Humanika, 2017 and "Developing a Persuasive Writing Model for Secondary School" in Educational Research for Policy and Practice, 2019.

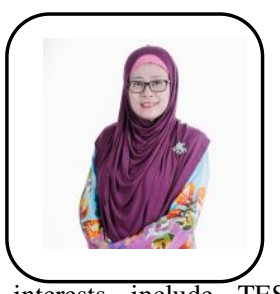

Dr. Seriaznita Bte Mat Said is a lecturer of UTM's Language Academy. She possesses a Bachelor's Degree in TESL from Universiti Malaya, aN MS TESL from Universiti Putra Malaysia and finally a Ph.D in TESL from Universiti Teknologi Malaysia. She has 24 years of teaching ESL at secondary \& tertiary levels. Her interests include TESL, Qualitative research, curriculum planning, communicative competence and learning needs. 